\title{
Preface to the Cornell Paperbacks Edition
}

The thesis of this book is that labor union political power in recent decades has been significantly underestimated by most observers. In particular, the resiliency of the alliance between organized labor and the Democratic party has been overlooked. While there is much in the pages that follow that supports such an interpretation, one fascinating piece of evidence was revealed only in the political maneuvers following the Monica Lewinsky scandal, which erupted in January 1998. By the spring of that year, the survival of Bill Clinton as president had grown uncertain as Republican members of Congress-and even a few Democrats-openly contemplated impeaching the president or at least forcing his early resignation. The cause of the contretemps was, of course, the revelation that Clinton had apparently lied under oath about his affair with the young White House intern. As Independent Counsel Kenneth Starr closed in on the president, Democrats in Washington grew increasingly anxious about the possible political impact of the president's misdeeds.

It was at this crucial moment, as described by the Washington Post's Peter Baker, that John J. Sweeney, president of the AFL-CIO, played a decisive role in discouraging any Democratic attempts to encourage Clinton to resign. As Baker recounts, Harold M. Ickes, Clinton's deputy chief of staff in his first term and a key figure in the reelection campaign of 1996, was deeply worried about the effects of the scandal on the party's fortunes in the upcoming congressional elections-not to mention the presidential election of 2000 . Ickes began approaching key players within the party about the possibility of a Clinton resignation, which would place Vice President Gore in the White House and could salvage the party's fortunes in 2000. Baker writes:

One of the power players that Ickes met with was John J. Sweeney, president of the AFL-CIO, still perhaps the single most dominant force within the Dem- 
ocratic Party even after decades of decline. Ickes and Sweeney got together over breakfast at the Washington Hilton Hotel, and the former White House aide presented his case. Sweeney listened but was not yet ready to abandon Clinton.

"Let's wait and see, Harold," he said. "Let's see how this unfolds."

With these words, the tide was turned: talk of resignation would go by the wayside, and Ickes ended his covert wanderings among Washington's political elites. Without Sweeney's support, bringing along other party figures would be a nearly hopeless task.

How could this be? How could it still be the case that, after decades of declining union representation in the workforce, the labor movement was "still perhaps the single most dominant force within the Democratic Party" and its top leader the most crucial figure in holding back a potential crisis of party unity? Hadn't the last rites already been performed over a dying U.S. labor movement at some point during the I980s?

This book provides the answers to these and other questions, explaining how organized labor still managed to generate valuable resources for exchange with elected officeholders in national politics. Contrary to some interpretations, I find that the level of workforce representation is not the crucial issue for the near-term potency of the labor movement in politics. Rather, what matters is the intensity of resource mobilization-how well labor does in generating votes, volunteers, propaganda, and money-and the overall unity of the movement as it interacts with Washington policymakers. In a special postscript to this edition, these factors are considered once more in the context of the 2000 election and the last years of Clinton's presidency. I conclude that labor's success at generating new resources bodes well for the maintenance of the labor movement as an influential force in national politics, albeit a force much weaker than union leaders and their sympathizers would like. John J. Sweeney-or his successor-will continue to be a major player in the Washington community.

TAYLOR DARK

Kyoto, Japan

'Peter Baker, "The Breach: White House Unhinged," Washington Post Sept. 18, 2000. See also Peter Baker, The Breach: Inside the Impeachment and Trial of William Jefferson Clinton. New York: Scribner, 2000. 